\title{
Review
}

\section{Political theology: A critical introduction}

\author{
By Saul Newman \\ Polity Press, Cambridge, 2019, vii + 198 pp., \\ ISBN: 9781509528400
}

Contemporary Political Theory (2020) 19, S225-S229. https://doi.org/10.1057/s41296019-00325-z; Published online 9 May 2019

Saul Newman's new critical introduction to political theology appears at a time when scholarly interest in the dialogue between politics and theology is peaking. Compared to the existing introductory texts, however, such as those by Michael Kirwan and Elizabeth Philips, which are written from the perspective of the theologian, Newman's text addresses political theorists, explicitly reading political theology as a discourse of power. Indeed, Newman's argument is that political theology is a modern invention the rise of which paradoxically overlaps with the gradual displacement of religion from the public space since early modernity. In trying to fill the empty space of transcendence caused by the retreat of religion, secular political power - be it in the form of traditional sovereignty, global economic governance or 'the reign of technics' (p. 148) - has appropriated the symbolic resources of theology. Despite the formal decline of the influence of religious ideas in public discourse, secular power structures have usurped, or competed to occupy, the place of the sacred (religion's transcendent dimension) around which societies construct their principles of legitimacy and representation.

In the first chapter, Newman establishes what is behind 'the permanence of the Theologico-Political', as Lefort put it. Picking up on Carl Schmitt's influential association of the modern concept of sovereignty with divine transcendence, he argues that Schmitt's notorious sovereign state of exception was a politicaltheological weapon designed not so much to counter the threat posed by liberalism but rather the threat posed by more radical forms of politics, especially anarchism. Newman, however, admits that Schmitt's attack on anarchists, such as Mikhail Bakunin, for remaining trapped in the political-theological predicament, was probably right on the mark. The idea here is that revolutionary action, aiming either to capture or topple the state apparatus, remains wedded to the idea of power as organised around a sacred vacant space. Newman concludes the chapter with a consideration of alternative takes on the relationship between the political and the theological that contest Schmitt's symbiotic model, such as Leo Strauss' sharp distinction between revelation and reason, Peterson's rejection of the possibility of

(C) 2019 Springer Nature Limited. 1470-8914 Contemporary Political Theory Vol. 19, S3, S225-S229 
political theology, and Jacob Taubes' revolutionary apocalypticism that has strongly influenced Giorgio Agamben's messianism, too.

In the second chapter, Newman introduces a thinker whom he knows well from his previous work, Max Stirner, an early critic of secular humanism that, according to Newman, sustains the political-theological machine. Stirner is presented as a neglected prophet of a type of 'ethical anarchism' (p. 60) who preached a radical disengagement from power - as opposed to a revolution against it, which would only end up reproducing the new order's libidinal attachment to it. Newman insists that Stirner's useful concept of 'insurrection' and his proto-existentialist politics of egoism propose a mode of existence that is a living indictment to the politicaltheological logic of power, akin to the Pauline messianic vocation that opens up the possibility of living a truly this-worldly, profane life. The latter is offered as an antidote to the poison of political theology and denotes existence as this-worldly, contingent, vulnerable and (inter)dependent.

Having foregrounded the persistence of the political-theological apparatus, Newman then offers us an investigation into the reasons for its pervasiveness. In so doing, he delves into the psychoanalytical and, more specifically, Lacanian understanding of God as the Unconscious (which is another way of saying that Capitalism is the Unconscious). In addition to the Freudian myth of the murder of the 'primal father' as the psychosocial mechanism responsible for the entanglement of guilt and authority in organised societies, Newman turns to the Lacanian reelaboration of Freudian themes that explain how obedience to authority operates through the perverse logic of the transgression of the Law. Fidelity to the 'Name of the Father', the quilting point that stitches the symbolic texture of society together, has nothing to do with the rational processes of consent and contract, as perhaps Hobbes and Rousseau had imagined; it is rather the result of the complicated operation of desire that seeks to delay its own gratification. The obscene phantasmagorias of the postponement of desire's fulfilment that modern civilisation stages, can be seen both in the contemporary xenophobic, racist attacks against immigrants and other vulnerable populations, stigmatised as obstacles to our full enjoyment, and also in the transgressive conduct of buffoonish populist leaders who, by exposing power's arcanum imperium, i.e. its an-archic nature, in their parodic re-enactment of sovereignty, at once sustain its operation.

In the next chapter, Newman rehearses the Foucauldian argument that sovereign power after Hobbes no longer functions at the political-juridical level, but literally pervades the body politic through discipline and punishment. Insightfully, Newman demonstrates how power's mystification and its mutation into a force that controls and regulates populations can be traced back to the mediaeval doctrine of the King's Two Bodies. As Ernst Kantorowicz has superbly shown, the natural body of the king served only as the physical manifestation of his mystical body that never dies, thus securing the continuation of political authority and power's undying sway over the lives of individuals. Newman skilfully traces how, since the baroque era, 
sovereignty fed off various natural bodies: from the wretched bodies of the deposed and hapless baroque princes to the regulated and pacified bodies of the people in modern democracies. Newman's intuitive claim here is that sovereignty has become a kind of identity politics that recruits the libidinal power of the sacred in order to structure contemporary phantasies of control, 'a vehicle or imago for expressing what is imagined as a coherent collective identity - whether religious, cultural, or national' (p. 100). Today the modern theatre of sovereignty is staged not only by authoritarian leaders, but also by populist demagogues who seek to mobilise the people's pouvoir constituent, free from the reins of constitutional democracy.

Following a recently popular shift of emphasis from political to economic theology, Newman launches a critique of late capitalism's governance structures as secularised expressions of the economic mystery of divine providence. Borrowing insights from Max Weber's depiction of modernity as secularised Calvinism and Agamben's genealogy of the Christian concepts of oikonomia and glory, Newman offers a penetrating account of how the joint reign of neoliberal economics and the communicative technologies of global governance have produced a new divine economy of techno-capitalism that perpetuates debt and distributes inexpiable guilt. Walter Benjamin's trenchant remarks about the way capitalism assumes the characteristics of a religion without redemption are here complemented with Newman's perceptive criticisms of the new homo connectus, the product of a world of neurotic hyper-connectivity (the world of social media, smartphones and interconnected electronic devices) making private lives a public spectacle and bearing the potential to achieve total surveillance and control.

Newman's prescribed remedy to this apocalyptic, almost despairing predicament is a politics of profanation that would remove the spell of political theology and deliver us from our enthralment to the absent, but sacred, centre of sovereign biopower. His guide in this task is mainly Foucault and his idea of ascesis as a spiritual praxis of reconnection with ourselves, as creatures who engage in practices of truth-telling and self-improvement. This is slightly ambiguous since Foucault's analysis of the confessional subject produced by Christianity is rather related to mechanisms that result in the subject's enslavement to power (the latest manifestation of the confessional machine being, in Newman's words, the 'hysterical moralising', and 'neo-puritan prudishness' and criminalisation currently surrounding sexual politics). That said, as Newman effectively reminds us, Foucault's emphases on the ancient parrhesiast and on alternative practices of selfformation were aimed at the production of a dissident individual able to resist capture by the forces of biopolitical governance and engaged in forms of countercultural counterconduct that could escape the allure of sacrality. This latter part of Newman's argument is accompanied by references to Benjamin's messianic eschatology as well as by a couple of scattered allusions to the Pauline meontology

(c) 2019 Springer Nature Limited. 1470-8914 Contemporary Political Theory Vol. 19, S3, S225-S229 S227 
of messianic life as an alternative vocation that cancels all other vocations without directly opposing them. The upshot here is the need to imagine a form-of-life capable of escaping entrapment by the political-theological machine that a direct revolt against the sacredness of power enacts. Newman imagines that such politics, corresponding directly to a model of 'political spirituality', as opposed to theology, would advocate a different relationship to nature, ultimately authorising a counterapocalyptic ecological politics.

This is a remarkable and wide-ranging achievement, yet a few questions remain. If the aim is to imagine a viable alternative to the paradigm of political theology, one wonders why adequate attention was not paid to Agamben's work - a pioneer in effectively working out a full-blown politics of profanation (prominent critics of political theology, such as Roberto Esposito and Massimo Cacciari, also come to mind). Especially in his The Highest Poverty (2013) and The Use of Bodies (2015), Agamben expands on how the political-theological apparatus can be rendered inoperative, what a profane form-of-life may look like, and how such a perspective may open up both theology and politics to a new 'an-archic' use. Agamben may have also helped Newman eschew the danger of parochialism, or what I would call the temptation of a new eco-sacrality, where the space of transcendence is occupied by an idealised conception of nature or ecopolitics. I am sure Newman would agree that a credible call for the profanation of politics should not authorise new forms of eco-piety or techno-phobia (like Ivan Illich's ideas of 'de-growth' and the 'right to frugality' that he seems to endorse), but should rather promote the radicalisation of our current nihilist predicament towards the modal transfiguration of our relationship with our natural and artificial environment.

That brings me to my last critical remark. If theology or politics is not to blame per se but only the use power makes of them, and if, as Newman himself admits, theology is also capable of offering us resources for an eco-friendly outlook on political life, one that affirms this-worldly priorities, then perhaps Strauss' sharp distinction between Athens and Jerusalem, reason and revelation, is not the answer here. As Newman himself recognises in his positive references to Moltmann's theocentrism and Christian anarchism, theology may still gesture to an 'other life' (p. 130) or even 'become the way of affirming the eternal vocation of political philosophy' (p. 175). To take it even further, such a perspective may have been better served by Agamben's invitation to imagine politics and theology as occupying a zone of indistinction, where their mutual entanglement transforms both into something else, at once opening them up to a new use by a philosophy to come.

Overall, this is a rich and erudite book that does a lot more than simply offer an introduction. It masterfully weaves together interpretive traditions that call for the demystification of authority and for resistance to new forms of enslavement to power - arising from both left and right - dressed up in the guise of freedom, 
insufferable moralising and illusions of control. Nothing less is at stake here, as Newman rightly points out, than the very conduct of free, rational enquiry.

\section{References}

Agamben, G. (2013) The Highest Poverty: Monastic Rules and Form-of-Life. Stanford: Stanford University Press.

Agamben, G. (2015) The Use of Bodies. Stanford: Stanford University Press.

Publisher's Note Springer Nature remains neutral with regard to jurisdictional claims in published maps and institutional affiliations.

Vassilios Paipais

University of St Andrews, St Andrews KY16 9AX, Scotland, UK vp31@st-andrews.ac.uk 